\title{
INTERPRETATION OF SURFACE GEOCHEMICAL DATA AND INTEGRATION WITH GEOLOGICAL MAPS AND LANDSAT-TM IMAGES FOR MINERAL EXPLORATION FROM A PORTION OF THE PRECAMBRIAN OF URUGUAY
}

\author{
JOSÉ MARIA FILIPPINI-ALBA ${ }^{1}$, ÁLVARO PENTEADO CRÓSTA ${ }^{2}$ \\ \& SÔNIA MARIA BARROS DE OLIVEIRA ${ }^{3}$
}

\begin{abstract}
RESUMO INTERPRETAÇÃO DE DADOS GEOQUÍMICOS SUPERFICIAIS E SUA INTEGRACCÃO COM MAPAS GEOLÓGICOS E IMAGENS DIGITAIS LANDSAT-TM PARA EXPLORAÇÃO MINERAL EM UM SETOR DO PRÉ-CAMBRIANO URUGUAIO Informações de mapas geológicos, dados geoquímicos e imagens digitais Landsat-TM correspondentes a um setor do embasamento cristalino uruguaio foram integrados utilizando técnicas estatísticas, sistemas de processamento digital de imagens e sistemas de informação geográfica (SIG). Foram consideradas 2.172 amostras de sedimentos de corrente e solos, analisadas para 22 elementos por espectrometria DCP. Os elementos Fe, Mn, $\mathrm{P}, \mathrm{Ba}, \mathrm{Co}, \mathrm{Cr}, \mathrm{Cu}, \mathrm{Ni}, \mathrm{Pb}, \mathrm{V}, \mathrm{Y}$ e $\mathrm{Zn}$ apresentaram variância adequada e erros analíticos inferiores a $10 \%$. Já os elementos Ag, As, B, Be, Cd, Mo, Nb, Sb, Sn e W tiveram um número significativo de amostras com teores abaixo dos limites de deteç̧ão analíticos e erros analíticos superiores a $15 \%$. Por esse motivo, o processamento estatístico incluiu todas as amostras do primeiro grupo de elementos, enquanto que, para o segundo grupo, apenas as amostras com valores próximos ou acima dos limites de detecção foram utilizadas. Deparou-se com alguns problemas relacionados à amostragem e à existência de outliers, que foram corrigidos de duas formas: (i) usando as medianas dos grupos de acordo com o material amostrado; (ii) eliminando os outliers. Após essas correções o conjunto de dados resultante apresentou comportamento mais homogêneo. A resposta geoquímica foi controlada por variaçöes relacionadas às unidades geológicas, aos litotipos e à ocorrência de mineralizações. Foram definidas várias anomalias regionais e nove setores anômalos, alguns dos quais foram considerados anomalias litológicas. A integração da informação geoquímica e de feições extraídas das imagens Landsat, através de técnicas de classificação, permitiu discriminar anomalias regionais relacionadas a elementos metálicos, anomalias litológicas e associações com mineralizações, além de ter evidenciado novos alvos prospectivos. A aplicação de técnicas de SIG permitiu reduzir o tamanho dos alvos e estabelecer uma hierarquia relativa ao seu potencial mineral.
\end{abstract}

Palavras-chaves: Geoquímica, prospecção mineral, sensoriamento remoto, geoprocessamento.

\begin{abstract}
Geological map information, geochemical data and digital Landsat-TM imagery were processed and integrated for a portion of the Precambriam basement of Uruguay based on statistical and image processing techniques and geographic information systems. Stream sediments and soil samples were collected at 2,172 sites and analysed for 22 elements by DCP spectrometry. The elements Fe, Mn, P, Ba, Co, $\mathrm{Cr}, \mathrm{Cu}, \mathrm{Ni}, \mathrm{Pb}, \mathrm{V}, \mathrm{Y}$ and $\mathrm{Zn}$ showed adequate variance and analytical errors lower than $10 \%$. A number of samples had the elements $\mathrm{Ag}$, As, $\mathrm{B}, \mathrm{Be}, \mathrm{Cd}, \mathrm{Mo}, \mathrm{Nb}, \mathrm{Sb}$ and $\mathrm{W}$ with contents lower than the analytical detection limits and analytical errors greater than $15 \%$. For these reasons, stastistical processing was carried out for the samples from the first group of elements, whereas, for the second group, only samples with contents near or above the detection limits were used. Some problems were found in relation to the sampling methodology and statistical outliers. These problems were corrected: (i) through the use of median values for groups of elements; (ii) eliminating the outliers. The final data set showed a more homogeneous signature. Several regional anomalies and nine anomalous sectors were defined and related to lithological factors or to known mineralization. Classification techniques using geochemical data and features extracted from Landsat-TM imagery discriminated regional-, lithological- and mineralization- related anomalies and new areas with potential for containing mineral deposits were detected. The use of GIS techniques allowed to reduce the size of the potential areas and to establish hierarchical levels related to the mineral potential.
\end{abstract}

Keywords: Surface Geochemistry, Mineral Exploration, Remote Sensing, Geoprocess.

\begin{abstract}
INTRODUCTION The integration of geological and exploration data by digital image processing techniques (Crósta 1993) and geographical information systems (Bonham-Carter 1994) has been addressed recently as a key tool for mineral exploration. Using this approach, a great amount of historical and recent data may be processed, integrated and analyzed, allowing new exploration scenarios to be established (Bonham-Carter et al. 1988, Kuosmanen et al. 1988, Harris 1989, Silva 1993, Crósta 1991, Tiainen \& Viita 1994).

Although mining activities are quite restricted in Uruguay, during the 80 s some exploration surveys were carried out for base metals. The "Mineral Inventory of Uruguay" was carried out by the Bureau of Recherche Geologique et Miniere-BRGM, in France, and the Uruguayan Institute of Mining and Geology-DINAMIGE (IGUBRGM 1982) and included a regional geochemical survey of soils and stream sediments, mostly in the Precambrian basement and covered $15 \%$ of the national territory, with a density of one or two samples per square kilometer. The samples were digested with a mixture of acids and analyzed by plasma spectrometry for 22 elements (Fe, Mn, P, Ag, As, B, Ba, Be, Cd, Co, Cr, Cu, Mo, Nb, Ni, Sb, Sn, Pb, V, W, Y e Zn), initially by the BRGM, and later by the DINAMIGE. Au and $U$ were analyzed independently and sometimes without overlapping the
\end{abstract}

multivariate data. Together with geochemical sampling, geological mapping at a scale of 1:50,000 was carried out, including all the sheets of the surveyed area.

The maps produced by the "Mineral Inventory" covered large areas and were not intended for mineral exploration. Fesefeldt (1988) tried to minimize this problem, by re-interpreting these maps using a geotectonic approach. Other authors have carried out studies in the same direction, such as Fragoso-César et al. (1987), but a geotectonic model is not available for the region yet.

This study is part of Ph.D. thesis of first author that it was oriented by second and third authors. Analytical results of 2,200 samples corresponding to "Mineral Inventory" were used. The elements U and Au were not considered, since the former was not measured and the latter was only analyzed locally, near an old mine. Detailed statistical processing was applied to the geochemical data and the results were integrated with the available geological maps and with Landsat Thematic Mapper (TM) imagery, based on digital image processing and geographical information system techniques. The objective of the study was to characterize the regional geochemical background in order to identify local anomalies and improve the existing geological maps, as well as to detect new mineral occurrences. 
GEOLOGICAL AND GEOGRAPHICAL CHARACTERISTICS

OF THE STUDY AREA The study area covers approximately $2,200 \mathrm{~km}^{2}$ and has a polygonal shape (Fig. 1). The main locality within the area is Varela, a village with nearly 2,000 inhabitants. Landsat TM images showed that $70 \%$ of the area is covered by natural grasslands, $15 \%$ by shrub-type vegetation or wetlands, $7 \%$ correspond to rock outcrops, lithosoils or land prepared for crops, $5 \%$ by native forests concentrated along the main river channels, in particular the Cebollati river, and $2 \%$ correspond to water bodies.

The relief within the study area is gentle, with topographic elevation increasing towards west, reaching a maximum of 300 meters in the Zapicán region (NW sector). Temperatures range from $10-13{ }^{\circ} \mathrm{C}$ in July to $22-24{ }^{\circ} \mathrm{C}$ in January, with an average annual rainfall of 1,250-1,500 mm. Absolute temperatures show a strong contrast between summer and winter, from $-8^{\circ} \mathrm{C}$ to $+40^{\circ} \mathrm{C}$.

From the geological viewpoint, the region is situated in the transition between two orogenic cycles: (i). a Precambrian older cycle, corresponding to the formation of the Rio de La Plata Craton (Preciozzi et al. 1985, 1988) and; (ii). the Brasiliano Cycle, related to the Dom Feliciano Belt (Fragoso-Cesar et al. 1987). A synthesis of the geological compilation made by Fesefeldt (1988) is presented in Figure 2, including details of the 1:50,000 maps (Fay 1982a, b, c, Illanes 1982) and of the 1:100,000 maps (Preciozzi 1987a, b, Preciozzi \& Fay 1988).

The Phanerozoic geology comprises Cenozoic fine-grained undifferentiated sediments and Jurassic basalts of the Puerto Gómez Formation. A number of Cambrian syn-, late- and post-tectonic granites are emplaced into the Lavalleja Group or spatially related to it, showing different shapes, mineral composition and textures: (a) Pirarajá Granite, a granite-granodiorite batholith with equigranular to porphyritic texture; (b) two bodies of K-granite with granular texture,

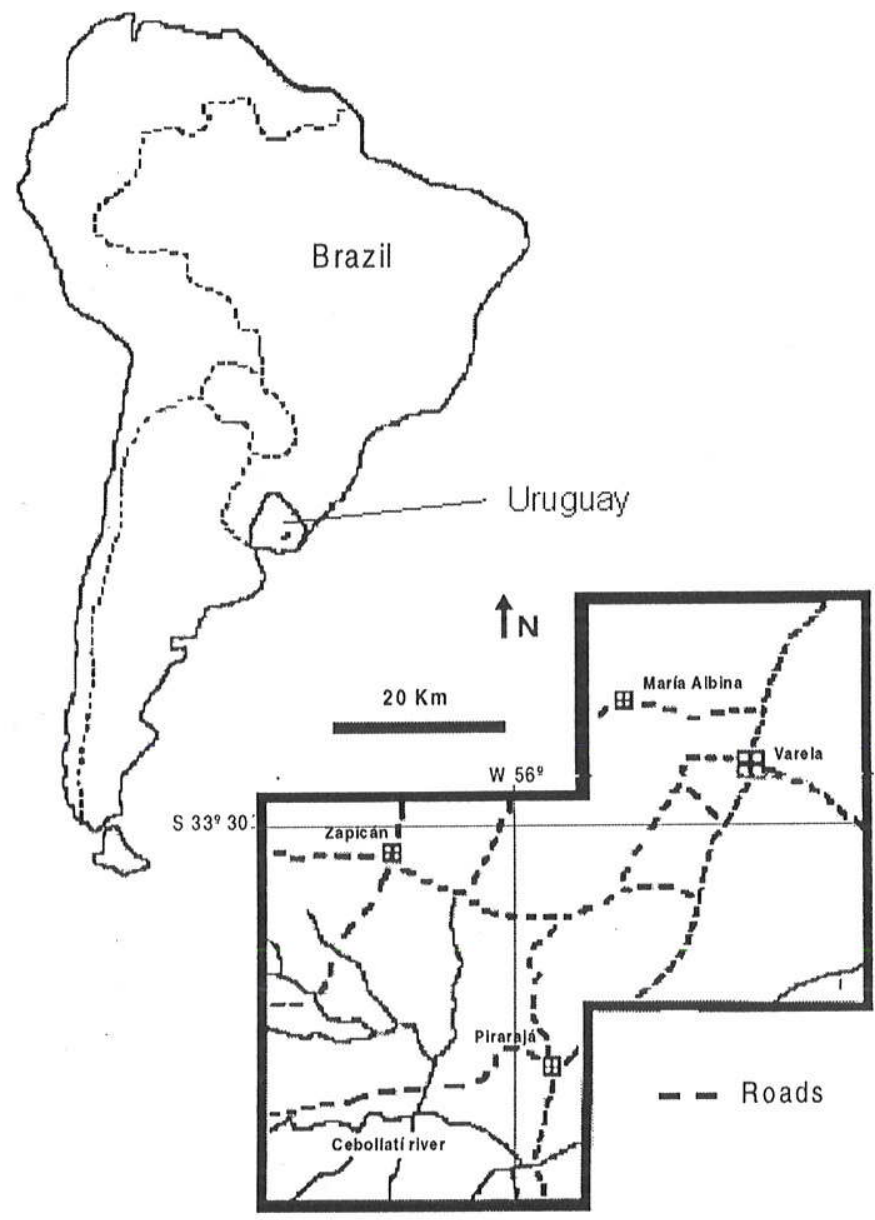

Figure I-Geographic location of the study area. abundant microcline and rare mica, characterized by Fay (1982b) as rapakivi-type granite; (c) María Albina Granite, a round-shaped granitic body showing schistosity at the border, perthitic microcline with small plagioclase crystals, quartz with two different textures (granular and network patterns around other mineral grains) and abundant biotite; (d) Zócalo del Este granite, corresponding to three granitic bodies, described as sub-alkaline, granular to microgranular texture, which show intense schistosity at the borders, and intercalation of

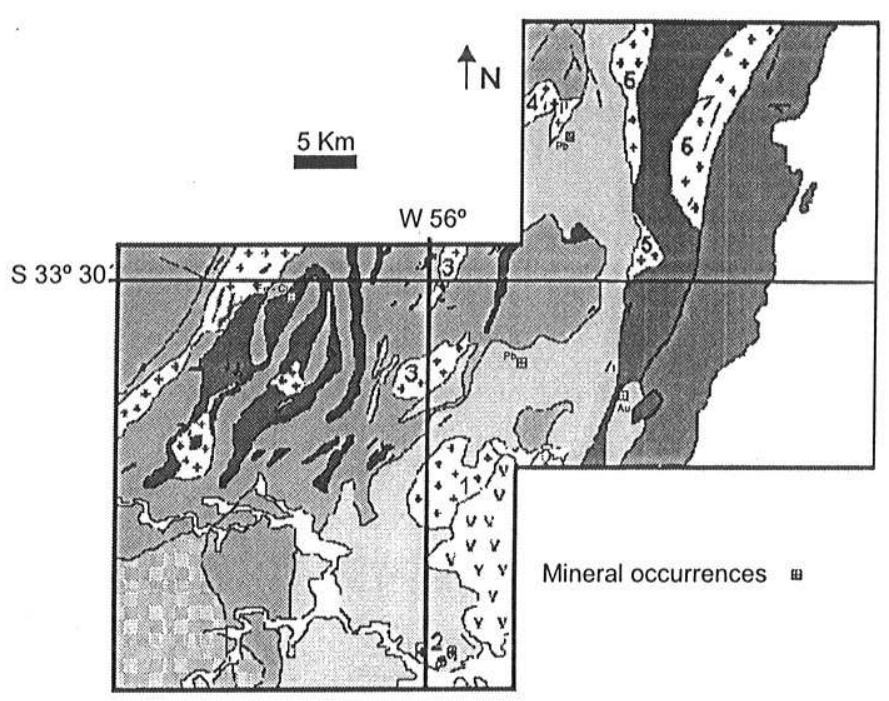

\section{Legend}

Cenosoic

- Undiferentiated sediments

Jurassic

- Puerto Gómez Formation

Cambriam - Late - Proterozoic

- Syn -, late - and post - tectonic Granites

1. Pirarajá Granite 2. Leuko Granites 3. K-Granites

4. María Albina Granite 5. Zócalo del Este Granites

- Mafic dyques

\section{Late - Proterozoic}

- Barriga Negra Group

- Lavalleja Group

\section{Early - Medium Proterozoic}

- Sierra Ballena Formation

- Anphibolites - Leptynites Formation

- Mafic - ultramafics Pavas Formation

- Gneiss and Granite Complex Pavas Formation

- Amphibole Granite Pavas Formation

Figure 2 - Geological features of the study area. Compiled from Fay (1982a, b. c), Illanes (1982), Preciozzi (1987a, b), Preciozzi \& Fay (1988) and Fesefeldt (1988). 
biotite and quartz-feldspathic portions (Preciozzi 1987a). Porphyritic dykes also cut the oldest units or the Lavalleja Group along the N30E direction, with a maximum width of 20 meters, comprising mafic matrix and amphibole and olivine phenocrysts, mapped as mafic dykes.

The Barriga Negra Group (Neoproterozoic) comprises nearly horizontal sedimentary rocks, such as limestone, siltstone, sandstone, conglomerate and breccia, typical of two different paleo-environments, a low-energy environment and a more energetic one. The former is characterized by fine-grained sedimentary rocks and the latter by breccias and volcanic macro-clasts.

The Lavalleja Group occurs also in the southern portion of Brazil and shows sedimentary and mafic volcanic rocks deformed during the Brasiliano Cycle. In the study region this unit comprises limestone and chalco-phyllites, with intercalations of sericite-chlorite phyllites, quartzites and sandstone.

The Sierra Ballena Formation (Meso to Paleo-Proterozoic) represents a sinistral shear zone of continental dimensions that controls the structural geology of Uruguayan and Sul-Rio Grandense Shield and its Phanerozoic cover, determining the distribution, nature and age of the adjacent lithologies (Gomes-Rifas 1995). Preciozzi (1987a) described the occurrence of blastomylonites of variable texture, with phenocrysts of K-feldspar elongated in the direction of the main stress, surrounded by a microcrystalline net of quartz, plagioclase, biotite and transformed minerals (sericite, chlorite and Fe-oxides).

The Amphibolites-Leptynites Formation was defined by Fesefeldt (1988), who interpreted it as the basement of the Lavalleja Group, based on the spatial distribution of both units and on the higher metamorphic grade of the Amphibolites-Leptynites Formation. It comprises microgranular amphibolites and fine-grained leptinites, together with gneiss.

The Pavas Formation has the oldest rocks in the area (PaleoProterozoic?), containing an alternation of mafic and felsic rocks, subjected to medium to high-grade metamorphism. This unit has a kilometric width and shows a NOE-N30E general direction. The darker lithologies comprise amphiboles and amphibole-schists and the lighter leucocratic gneiss and leptinites. In the NW sector of this unit, three bodies of amphibole granites occur, containing plagioclase, quartz and biotite, alternating with mafic to ultramafic rocks.

The most important mineral occurrence in the area is an old gold mine, exploited in the 30 's and 40 's. The mineralization is hosted by a purple-colored quartz vein, less than 1 meter thick, with an average grade of $7 \mathrm{ppm}$ of gold, and pyrite and chalcopyrite as accessories. A pedo-chemical study showed the presence of a metric positive anomaly in the $\mathrm{C}$ horizon, related to the mineralization, with a ratio anomaly/ average grade higher than 1.5 for $\mathrm{Au}, \mathrm{Ba}, \mathrm{Co}, \mathrm{Cu}, \mathrm{Mn}, \mathrm{P}$ and $\mathrm{Pb}$ (Filippini-Alba 1990).

DATA AND METHODS Geochemical sampling was carried out from 1982 to 1986, in four stages of one month each, covering a total of 2,172 sampling localities in a total area of $2,480 \mathrm{~km}^{2}$, with an average of 87 localities per $100 \mathrm{~km}^{2}$. Duplicates of the sampling and/ or analysis were collected in 29 localities, to evaluate the quality and the precision of the geochemical information. Four different types of geological materials were sampled: sediments in terraces ou overbank sediments (1,935 samples), stream bed sediments (32 samples), alluvial soils (176 samples) and autochthonous soils (29 samples). Preference was given to overbank sediments but, in places where these could not be sampled, one of the other three types was collected. In each locality the $\mathrm{pH}$ of the water courses was measured using universal paper, as well as total count gamma radiometry using portable scintilometers of solid crystal detector.

All samples were dried at $50^{\circ} \mathrm{C}$, sieved at 80 mesh and analyzed using direct current plasma spectrometry for the following elements: $\mathrm{Fe}, \mathrm{Mn}, \mathrm{P}, \mathrm{Ag}, \mathrm{As}, \mathrm{B}, \mathrm{Ba}, \mathrm{Be}, \mathrm{Cd}, \mathrm{Co}, \mathrm{Cr}, \mathrm{Cu}, \mathrm{Mo}, \mathrm{Nb}, \mathrm{Ni}, \mathrm{Sb}, \mathrm{Sn}, \mathrm{Pb}$, $\mathrm{V}, \mathrm{W}, \mathrm{Y}$ an $\mathrm{Zn}$. Digestion of the samples was carried out in two stages: (i) $\mathrm{HClO}_{4}$ at $140^{\circ} \mathrm{C}$ and; (ii) addition of $\mathrm{HCl}-\mathrm{HF}$ at $80^{\circ} \mathrm{C}$. A similar treatment was performed for all samples collected as part of the Mineral Inventory of Uruguay Program. By othe hand, it was no possible to adapt all methods to IGCP 259 Project (Darnley et al. 1995). May be remarked that the authors used the analytical results of those samples to perform this study.

Landsat Thematic Mapper data correspond to path 223, row 83 (Landsat World Reference System-WRS), acquired on October, 16, 1990 and purchased from the Brazilian National Institute for Space Research (INPE). The data were rectified to the UTM map projection at the Laboratory for Geo-Referenced Information Processing (LAPIG), of the Geosciences Institute, University of Campinas (IGUNICAMP). The rectification was based on ground control points extracted from 1:50,000 topographic sheets on a digitizing table and using a nearest-neighbor resampling algorithm. Error for geometric correction was evaluated to $25 \mathrm{~m}$. Satellite data processing and their integration with the geochemical data were also done at the LAPIG/IGUNICAMP, through image processing and geographical information system (GIS) techniques, using respectively the software ER Mapper (ERM 1995) and Geographic Resources Analysis Support System (GRASS 1991).

Statistical and cartographic processing of the geochemical data were carried out in collaboration with the Åbo Academic University (Finland) and the Finnish Geological Survey. Among the software used there were SPSS (SPSS 1993), SYSTAT (SYSTAT 1992) and ALKEMIA (Ahlsved et al. 1991).

GEOCHEMICAL DATA PRE-PROCESSING This section presents and discusses the procedures for assessing the quality of the geochemical data. The precision of the data was evaluated using variance analysis, scattergrams and position plots for the analytical and sampling duplicates. The result of this analysis led to the definition of two groups of elements (Filippini-Alba 1998):

(A) $\mathrm{Ag}, \mathrm{As}, \mathrm{B}, \mathrm{Be}, \mathrm{Cd}, \mathrm{Mo}, \mathrm{Nb}, \mathrm{Sb}, \mathrm{Sn}$ and $\mathrm{W}$.

(B) Fe, Mn, P, Ba, Co, Cr, Cu, Ni, Pb, V, Y and Zn.

Elements belonging to Group A comprise those with analytical errors ranging from 17 to $122 \%$, due to the occurrence of several samples with contents below the lower detection limit. These elements were only considered when their contents were near or greater than the detection limit and they were not considered for further multivariate statistical processing.

Elements belonging to Group B showed analytical errors below $10 \%$ and, in some cases, higher sampling errors, some reaching $60 \%$. It is important to stress that sampling duplicates were collected at 100 meters interval from each other. This distance is too long from a geochemical variance point of view, especially taking into account the geological variations that are likely to occur in such short distances. For this reason, we concluded that sampling errors were superestimated and the elements belonging to Group B could be used for statistical processing, due to their low analytical errors. Another aspect that confirms this hypothesis is that mobile elements, such as $\mathrm{Cu}$ and $\mathrm{Zn}$, showed low sampling errors $(\sim 20 \%)$ and elements with less mobility, such as P, Y and Co, showed higher sampling errors (> 60 $\%)$.

Considering that several different geological materials were sampled, it was necessary to evaluate the geochemical response of each type. The medians obtained for the four types of materials are presented in Table 1. Except for $\mathrm{P}$, the variance analysis using the nonparametric Kruskall-Wallis test showed that, for each variable and with a significance level of $1 \%$, at least one of the medians differs from the others. It should be noted that the soil samples are really depleted in relation to the sediment samples, being necessary to apply a correction

Table I-Comparison of the medians of the overbank sediments, sediments in stream beds, alluvial soils and autochthonous soils, expressed as a percentage of the medians of the first type. $N=$ number of samples.

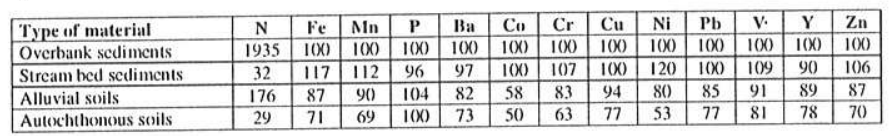


for homogenizing the response, in order to make possible the comparison among the four types of materials. Therefore, the samples for each type are expressed as a percentage of their respective median, thus minimizing the problem.

GEOCHEMICAL BACKGROUND AND REGIONAL ANOMALIES The geochemical variables used in the study showed an irregular distribution and were best fitted to a log-normal distribution. This suggests the existence of several sub-populations within the total population. It is therefore inadequate to evaluate the geochemical background using the statistical calculation of the total population. The best alternatives to overcome this problem are to characterize the sub-populations individually, or to perform a spatial analysis of the data (Filippini-Alba, 1998).

Figure 3 shows a comparison of the medians of the sub-populations for samples of sediments classified as a function of the lithotype, considering four chemical elements: $\mathrm{Cr}, \mathrm{Cu}, \mathrm{Pb}$ and $\mathrm{Y}$. Different lithotypes were ordered as a function of the age of the respective geological formation, with the Cenozoic sediments (younger formation) placed at the top of the $y$-axis and the subsequent domains placed at an decreasing order. $\mathrm{Cr}$ and $\mathrm{Cu}$ show a similar pattern (the variations are nearly the same for both elements, with a maximum usually related to mafic rocks) and, in general, different from $\mathrm{Pb}$ (usually shows a minimum when $\mathrm{Cr}-\mathrm{Cu}$ show a maximum). The pattern showed by the element $\mathrm{Y}$ is intermediate in relation to the previous elements. These variations appear to be related to geological time, but there are some local changes, related to the nature of the associated lithotypes. For example, $\mathrm{Y}$ and $\mathrm{Pb}$ show a very similar behavior in relation to the Cambrian granites, with a maximum for María Albina Granite, a minimum for Pirarajá Granite, a maximum for
Table 2 - Spearman correlation coefficients with $1 \%$ significance and expressed as percentages (times 100). A total of 2,144 samples were considered (28 extreme samples were eliminated). "No" represents the absence of correlation for this level of significance (1\%).

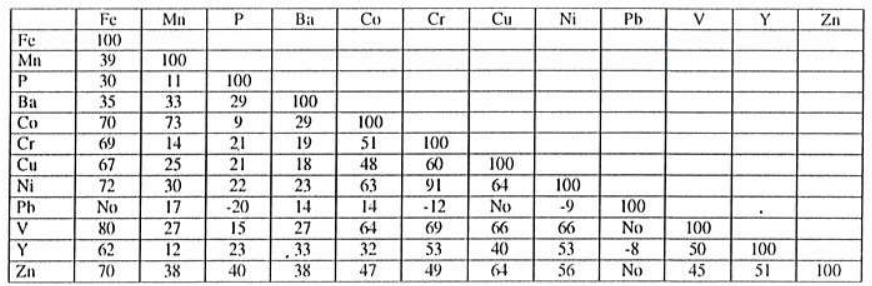

K-granite and a overall reduction of the signature for the Zócalo del Este Granite. $\mathrm{Cr}$ shows a similar behavior, with the exception of the Maria Albina Granite.

The dependence analysis shows a strong correlation between $\mathrm{Fe}$ and $\mathrm{Co}, \mathrm{Cr}, \mathrm{Cu}, \mathrm{Ni}, \mathrm{V}, \mathrm{Y}$ and $\mathrm{Zn}$ (Filippini-Alba 1998). This can be explained by the control of the geochemical variance by adsorption and co-precipitation of trace elements over ferric oxides and hydroxides. $\mathrm{Mn}, \mathrm{P}, \mathrm{Ba}$ and $\mathrm{Pb}$ do not show important correlation among themselves and with other elements. The occurrence of several negative coefficients for $\mathrm{Pb}$ appears to be related to the different behavior showed by this element when geochemical signature is considered as a function of the nearby lithology (Fig. 3).

Principal component analysis was used to assess the number of factors to be extracted in the $\mathrm{R}$ mode factor analysis. The parameters for calculating the four factors using the Varimax rotation are shown in Table 3. Factor 1 represents the association among compatible

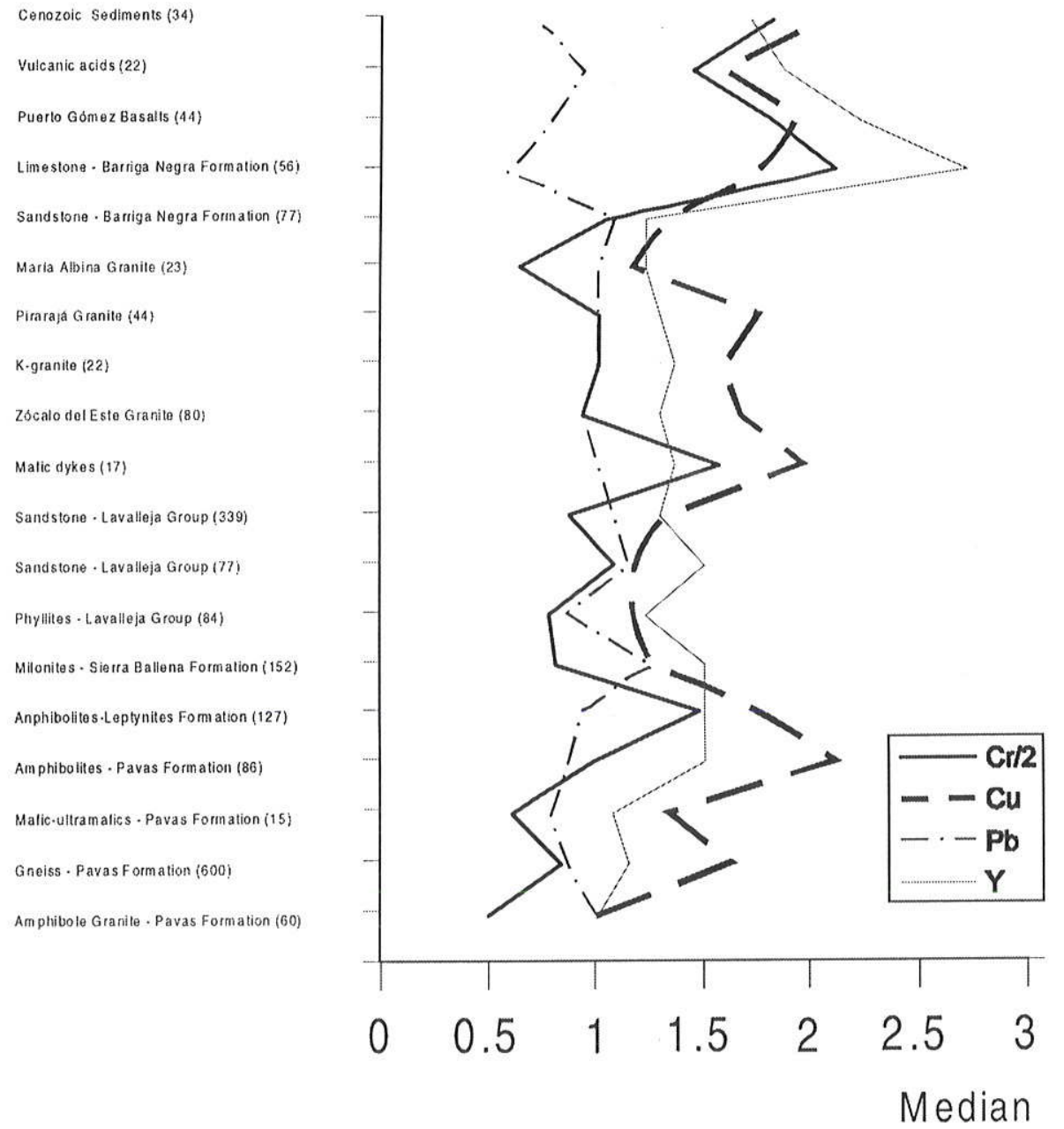

Figure 3 - Medians of groups of superficial geochemical samples classified by lithology of the nearest lithotypes. 
elements ( $\mathrm{Fe}, \mathrm{Co}, \mathrm{Cr}, \mathrm{Cu}, \mathrm{Ni}, \mathrm{V}, \mathrm{Y}$ and $\mathrm{Zn}$ ), which are concentrated in ferromagnesian minerals, due either to substitution in the inherited minerals, or to adsorption and co-precipitation in clay minerals or oxides derived from weathering. For this reason, the scores of factor 1 show high values related to the mafic rocks of the Pavas Formation (Fig. 4). The Lavalleja Group and the Barriga Negra Formation show an intermediate response for factor 1, whereas the Puerto Gómez Formation, some granitic bodies and the Sierra Ballena Formation show a weak signal, due to the depletion in ferromagnesian minerals.

Table 3 - Loadings (times 100) for the R-Mode Factor Analysis, with the extraction of four factors after the rotation. Logarithm of data was used for calculation and the influence of the material sampled was corrected. 44 extreme samples were discarded.

\begin{tabular}{|l|c|c|c|c|}
\hline Variable & Factor 1 & Factor 2 & Factor 3 & Factor 4 \\
\hline $\mathrm{Fe}$ & 80 & 33 & 28 & -10 \\
\hline $\mathrm{Mn}$ & 10 & 18 & 93 & 6 \\
\hline $\mathrm{P}$ & 12 & 69 & 10 & -47 \\
\hline $\mathrm{Ba}$ & 9 & 83 & 16 & 20 \\
\hline $\mathrm{Co}$ & 56 & 8 & 75 & 5 \\
\hline $\mathrm{Cr}$ & 90 & 2 & 2 & -15 \\
\hline $\mathrm{Cu}$ & 79 & 12 & 15 & 7 \\
\hline $\mathrm{Ni}$ & 89 & 5 & 18 & -10 \\
\hline $\mathrm{Pb}$ & -8 & 1 & 9 & 94 \\
\hline $\mathrm{V}$ & 83 & 15 & 19 & 3 \\
\hline $\mathrm{Y}$ & 57 & 45 & -17 & -20 \\
\hline $\mathrm{Zn}$ & 56 & 51 & 23 & -1 \\
\hline $\begin{array}{l}\text { Variance } \\
\text { associated } \\
\text { to each } \\
\text { factor }\end{array}$ & $47 \%$ & $13 \%$ & $11 \%$ & $7 \%$ \\
\hline
\end{tabular}

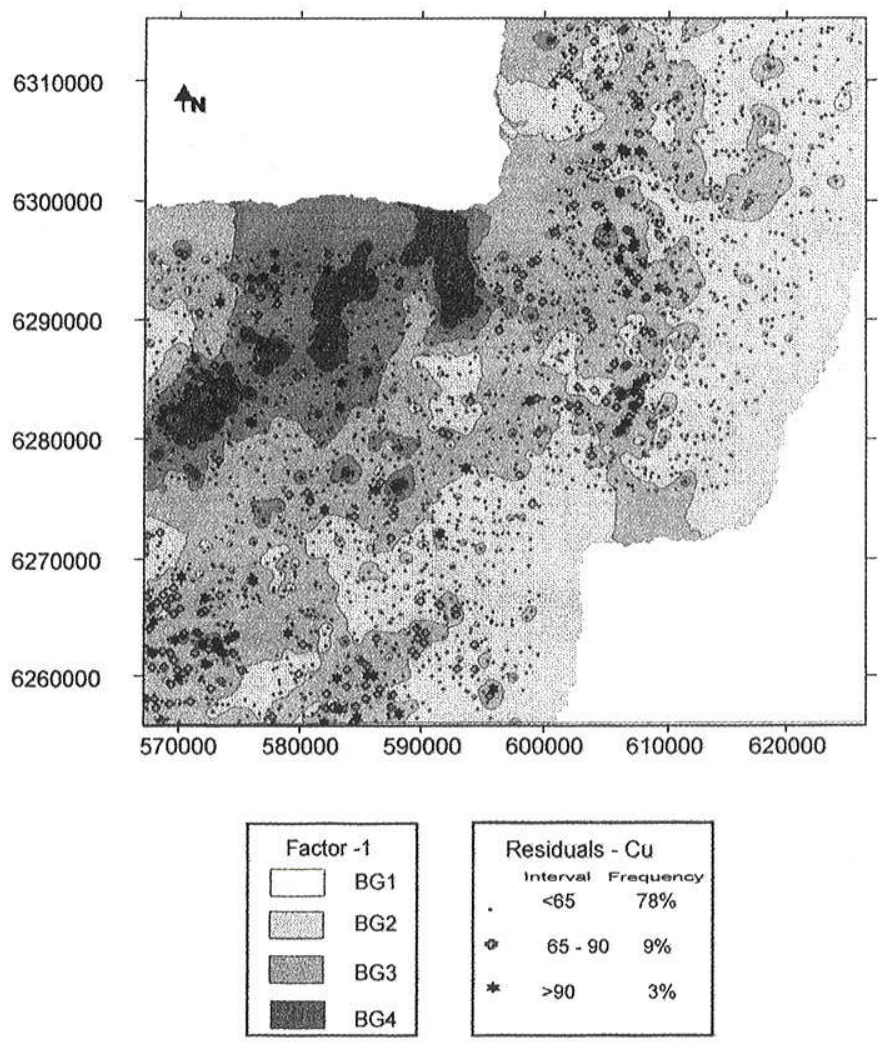

Figure 4-Distribution of Factor I and Cu residuals (real-Cu minus theoretical-Cu) as a function of factors.

Revista Brasileira de Geociências, Volume 31, 2001
Thus, factor 1 defines three well-differentiated domains, or three levels of regional geochemical background. The other factors are related to more specific and less significant phenomena: factor $2(\mathrm{P}, \mathrm{Ba}, \mathrm{Y}$ and $\mathrm{Zn}$ ), related to the formation of phosphates; factor $3(\mathrm{Mn}, \mathrm{Co}$ and partially $\mathrm{Fe}$ ) suggests the formation of $\mathrm{Mn}$ and Fe oxides.

LOCAL GEOCHEMICAL ANOMALIES The distribution patterns described above suggest a contrast between the compatible $(\mathrm{Co}, \mathrm{Cr}, \mathrm{Cu}, \mathrm{Ni}$, etc.) and incompatible elements $(\mathrm{Ba}$ and $\mathrm{Pb})$ in the Pavas Formation. This contrast can be interpreted as a consequence of the alternating kilometric-size belts of felsic and mafic rocks of this unit. On the other hand, chalcophile elements $\mathrm{Mn}, \mathrm{Co}, \mathrm{Cu}, \mathrm{Pb}$ and $\mathrm{Zn}$ ) predominate in the Lavalleja Group, probably due to its volcanic nature. The Barriga Negra Group showed a characteristic response of the geochemical elements, which differs from the previous two units, with intermediate contents of $\mathrm{Fe}, \mathrm{Mn}, \mathrm{Co}, \mathrm{Cr}, \mathrm{Ni}, \mathrm{V}$ and $\mathrm{Zn}$, higher contents of $\mathrm{Cu}$ and some anomalies of $\mathrm{Pb}$. The remaining units showed weaker geochemical responses, with only some isolated anomalies of $\mathrm{Mn}-\mathrm{Co}$

Among the procedures used for visualizing local anomalies, one of the most effective was the spacialization of $\mathrm{Cu}$-residuals using the regression model as a function of the factors:

$$
\begin{aligned}
\mathrm{Cu} & =0.0846 \mathrm{~F} 1+0.0125 \mathrm{~F} 2+0.0166 \mathrm{~F} 3+0.0072 \mathrm{~F} 4+1.009 ; \mathrm{FN} \\
& =\text { Factor }-\mathrm{N} ; \mathrm{N}=1,2,3,4
\end{aligned}
$$

This model accounted for $66 \%$ of the total $\mathrm{Cu}$ variance and showed some anomalies located near the four known mineral occurrences, with particular emphasis on the old Au mine in the southern portion of the eastern sector (Fig. 4), where the variable/average variation interval was 0.7-3.0 for the $\mathrm{Cu}$ original data and $0.5-4.7$ for the $\mathrm{Cu}$ residuals. $\mathrm{The} \mathrm{Pb}$ and $\mathrm{Zn}$ regression models were not as efficient in this sense, possibly as a result of their factors not being able to explain the variances of these elements in comparison to $\mathrm{Cu}$. The $\mathrm{Cu}$ residuals also enhanced the response of the Barriga Negra Formation and Lavalleja Group, therefore suggesting a greater metallogenic potential for these units.

The procedure described above, together with the use of dot maps for $\mathrm{Ag}, \mathrm{As}, \mathrm{Pb}, \mathrm{Sn}, \mathrm{W}$ and $\mathrm{Zn}$, allowed the definition of nine anomalous sectors, which will be discussed in the next section. It should be pointed out that, as Ag, As, Sn and W showed high analytical errors, only the samples with contents above or near the detection limits were considered.

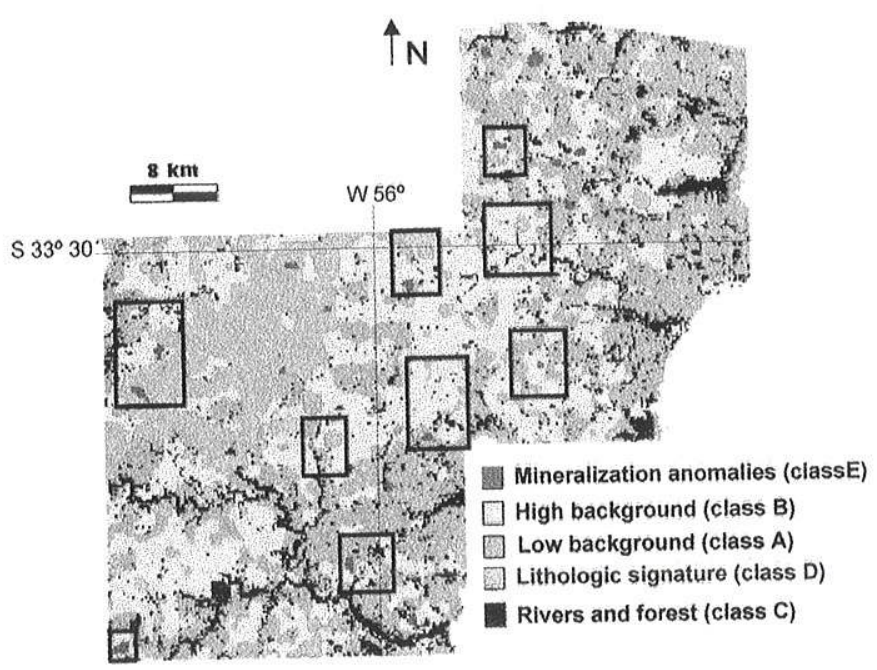

Figure 5 - Unsupervised classification considering 14 variables (TM Band 4. F-Factor; H-Factors, $\mathrm{Ba}, \mathrm{Co}, \mathrm{Cu}, \mathrm{Ni}, \mathrm{Pb}, \mathrm{Cu}, \mathrm{Mn}, \mathrm{Ni}, \mathrm{Pb}, \mathrm{P}, \mathrm{V}, \mathrm{Y}, \mathrm{Zn}$ and gamma-ray radiometry). The original twelve classes were re-grouped into five classes. 
DATA INTEGRATION TO spatially integrate satellite and geochemical data, digital image processing and geographical information systems (GIS) techniques were employed and compared. In this paper, we present the results of two of these techniques: (1) unsupervised classification using fourteen variables generated from both, satellite and geochemical data and; (2) spatial analysis in a GIS based on the application of a non-weighted logical sequence using boolean operators, and on theoretical exploration models.

Unsupervised classification was carried out in ER Mapper, using the ISODATA algorithm. Fourteen variables were used in the classification: TM Band 4, F-Factor, H-Factors, $\mathrm{Ba}, \mathrm{Co}, \mathrm{Cu}, \mathrm{Ni}, \mathrm{Pb}$, $\mathrm{Cu}, \mathrm{Mn}, \mathrm{Ni}, \mathrm{Pb}, \mathrm{P}, \mathrm{V}, \mathrm{Y}, \mathrm{Zn}$ and gamma-ray radiometry. TM Band 4 , Factor-F and Factor-H refer to Landsat TM data, as explained next, gamma-ray radiometry as explained before, whereas the other variables are related to geochemical data.

TM Band 4 was used due its spectral information content related to vegetation, since it is spectrally positioned in the near infrared portion of the electromagnetic spectrum (from 760 to 900 nanometers). This is a wavelength range in which the vegetation has its maximum reflectance, thus allowing to distinguish it from other surface materials. F-Factor and H-Factor represent the results of the Feature-Orientated Principal Component Selection (FPCS) technique (Crósta \& Moore 1989, Loughlin 1991, Crósta \& Rabelo 1993). This technique allows to derive spectral information due to the presence of iron oxides/ hydroxides (F-Factor) and hydroxil-bearing minerals (H-Factor) from a Landsat-TM multispectral data set and use this information as an indicator of the presence of hydrothermal alteration processes. According to classification procedures, $90 \%$ of the area was covered by grass, forest or other vegetation forms, thus, interference problems will be expected. Anyway, results were discussed since a experimental point of view, as it will be showed in the next sections.

Geochemical data were transformed into a regular grid using the software SURFER (SURFER 1994). A minimum curvature interpolation method was used to generate the grid, which was then converted into a 8-bit raster image, for integration with the satellite imagery. Each element then produced a "geochemical image", in which the intensity of each pixel (gray level) was proportional to the content of the respective element. The spatial resolution (pixel size) of the geochemical images was defined as 200 meters. This value was defined using scattergram of "pixel averages" against "resolution". All elements showed a flat curve for resolution greater than 150-200 meters. This means that for pixel sizes of 150-200 meters we have the transition between local and regional geochemical effects. The greatest value (200 meters) was selected to reduce the size of the computational files. Landsat TM data were resampled to 200 meters.

Unsupervised classification of the 14 variables using ISOCLASS produced 12 original classes, which were subsequently re-grouped into 5 classes in Figure 5, according to their size, spatial distribution, superposition with geologic map and geochemical - geophysical features. These 5 classes are described next:

- Class A: comprises the most depleted pixels, representing the low geochemical background. This class was used for comparison purposes with the other classes, using the following criterion: depleted/enriched classes were those whose median were lower/ higher than one standard deviation of the median of Class A. This class is spatially correlated to the Amphibolites-Leptynites Formation, to the Sierra Ballena Formation and to the Phanerozoic sediments and covers an area corresponding to $28 \%$ of the study area.

- Class B: comprises those pixels showing a moderate enrichment in $\mathrm{Co}, \mathrm{Cu}, \mathrm{Ni}$ and $\mathrm{Zn}$ in relation to Class $\mathrm{A}$. This class represents the high geochemical background. It is spatially correlated to the Lavalleja Group and to the Barriga Negra Formation, covering an area which represents $28 \%$ of the total area.

- Class C: comprises the pixels related to the main water courses and vegetated areas, with no geological interest. It represents $8 \%$ of the total area.

- Class D: comprises the pixels related to lithologic anomalies, such as enrichment in $\mathrm{Ba}, \mathrm{Co}, \mathrm{Cu}, \mathrm{Mn}, \mathrm{Ni}, \mathrm{V}, \mathrm{Y}$ or $\mathrm{Zn}$, with depletion of $\mathrm{Pb}$. It is spatially related to the Pavas Formation, covering $26 \%$ of the total area.

- Class E: comprises pixels enriched in terms of F-Factor and $\mathrm{Pb}$, or in $\mathrm{Co}, \mathrm{Pb}, \mathrm{Mn}$ and gamma-ray radiometry, with depletion of $\mathrm{Ni}$ in both cases. This suggests an association with mineralized areas, which is confirmed by the spatial correlation with the known mineral occurrences and with the local geochemical anomalies. It represents $10 \%$ of the total area.

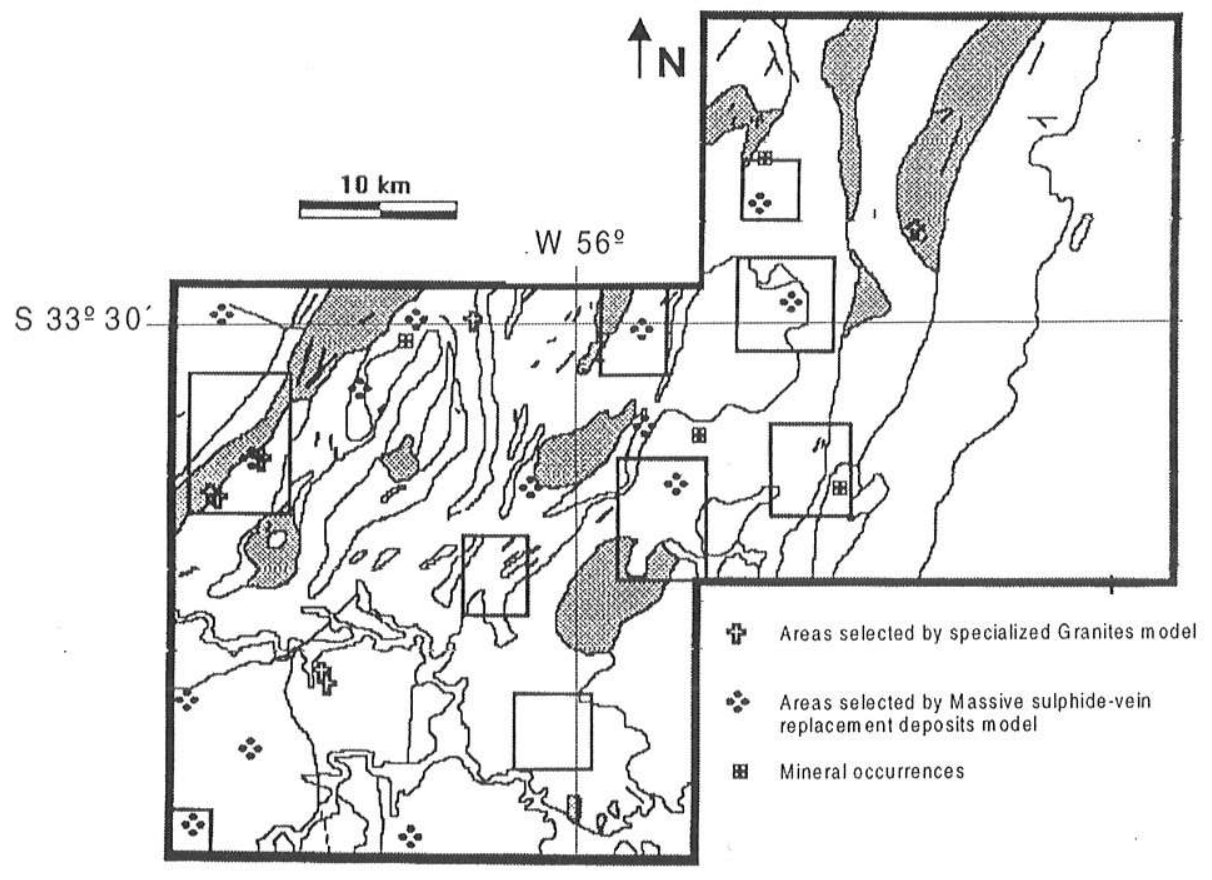

Figure 6 - Areas selected by non-weighted processing, according to the following models: specialized granites, massive sulfide and vein replacement deposits. Granite bodies are shown in gray for better visualization. 
According to Govett (1983) e Govett \& Atherden (1988), some mineral deposits and rocks associated with mineralization have geochemical contents which are characteristic of certain elements. In the context of the study area, three types of mineral deposits were taken into account: massive sulfide deposits, vein replacement deposits and deposits associated with specialized granites.

Volcano-sedimentary massive sulfide deposits usually depict regional positive anomalies of $\mathrm{Fe}, \mathrm{Mg}$ and $\mathrm{Zn}$, sometimes $\mathrm{Mn}$. These regional anomalies show local variations and can be associated with $\mathrm{Na}-\mathrm{Ca}$ depleted zones, with dimensions of some hundreds to greater than 1,000 meters. Positive anomalies of smaller dimensions are associated to trace elements in ore $(\mathrm{Cu}, \mathrm{Pb}, \mathrm{Zn}$, etc.). There is little knowledge about enrichment in $\mathrm{Co}, \mathrm{H}_{2} \mathrm{O}$ and $\mathrm{Rb}$ and depletion in $\mathrm{Ni}$ and $\mathrm{Sr}$ at local scale.

Vein replacement deposits depict positive regional anomalies in As, $\mathrm{Sb}, \mathrm{Te}$ and $\mathrm{Bi}$, and positive local anomalies in $\mathrm{Ag}, \mathrm{Au}, \mathrm{Cu}, \mathrm{Pb}$ and $\mathrm{Zn}$.

Specialized granites are usually enriched in $\mathrm{Li}$ and $\mathrm{Rb}$, depleted in $\mathrm{Mg}, \mathrm{Ba}$ and $\mathrm{Sr}$, with a high ratio $\mathrm{Rb} / \mathrm{K}$. These granites may be associated with mineralization in $\mathrm{Sn}, \mathrm{U}, \mathrm{Th}, \mathrm{W}$ and, sometimes, $\mathrm{Cu}$, $\mathrm{Mo}, \mathrm{Pb}$ or $\mathrm{Zn}$, with $\mathrm{Sn}$ and $\mathrm{U}$ being related to the degree of specialization of the granite.

These criteria were adapted to stream sediment geochemistry, as a function of the available information for this study. The logical sequences taken into account for the spatial analysis in the GIS environment were:

1.Massive sulfide and vein replacement deposits:
(a) $\mathrm{Fe}>105$ AND $\mathrm{Zn}>105$
(b) (a) AND Ni $<95$;
(c) As > 80 OR $\mathrm{Cu}>120$ OR $\mathrm{Mn}>105 \mathrm{OR} \mathrm{Pb}>120$;
(d) (b) AND (c);
(e) $\mathrm{Cu}>120$ AND $\mathrm{Zn}>105$;
(f) $\mathrm{Pb}>120$ AND $\mathrm{Zn}>105$;
(g) (e) AND (f);
(h) (g) AND Ni $<85$;
(i) (h) AND Fe > 105;
(j) (d) OR (i)

\section{Specialized granites}

(a) Gamma-spectrometry $>105$ AND Ba $<96$;

(b) $\mathrm{Ba}<96$ AND $\mathrm{Sn}>80$;

(c) (a) OR (b)

(d) $\mathrm{Cu}>120 \mathrm{OR} \mathrm{Pb}>120$ OR $\mathrm{Zn}>105$;

(e) (c) AND (d)

It should be noted that the values mentioned above are transformed by the medians or, in the case of As and Sn, by the detection limits. Thus, they are not expressed in real units, as ppm or ppb. The choice of each value was based on the histograms of each geochemical image, as to represent the depletion or the enrichment of the element. Spatial analysis using these logical sequences was carried out with GRASS (GRASS, 1991).

A synthesis of the resulting map is shown in Figure 6. Six geochemically anomalous areas (rectangles) were confirmed by this method. Three aspects must be emphasized: (1) Three areas selected by the massive sulfides-vein replacement model are spatially close to the two galena occurrences and the pyrite-chalcopyrite occurrence. (2) Several selected areas are close to the border of the granites, which makes them potential exploration targets. (3) The old Au mine was not explained by any of the models. This sector is related to vein replacement deposits, that it was included shyness in model 1. First condition, related to $\mathrm{Fe}$ and $\mathrm{Zn}$ regional anomalies in massive sulfide deposits, was not verified.

CONCLUDING REMARKS Processing and integration of geochemical data using image processing and GIS techniques allowed the definition of several regional anomalies, two of which of particular interest. The first one, located in the vicinity of Zapicán, covers an area of more than 100 square kilometers and is related to the occurrence of mafic and ultramafic rocks of the Pavas Formation, depicting enrichment in $\mathrm{Fe}, \mathrm{Mn}, \mathrm{P}, \mathrm{Ba}, \mathrm{Cr}, \mathrm{Co}, \mathrm{Ni}, \mathrm{V}$ and $\mathrm{Zn}$ and depletion in $\mathrm{Pb}$. The second anomaly, located near Maria Albina, has smaller dimensions and is related to one of the intrusions of the Zócalo del Este granite, being characterized by high $\mathrm{Pb}$ and/or $\mathrm{Sn}$ contents and surrounded by local anomalies in $\mathrm{As}, \mathrm{Cu}, \mathrm{Pb}$ and $\mathrm{Zn}$.

The major geological units that occur in the study area showed local variations in terms of their geochemical responses. The Pavas Formation showed variations as a function of the existence of mafic and ultramafic rocks, whereas Lavalleja Group geochemical signature was related to the occurrence of mineralization or of small outcrops of specific lithotypes. The geological units with smaller dimensions depicted a more homogeneous response, with the Barriga Negra Group pointing out due to its high contents in $\mathrm{Cu}$.

The processing techniques allowed to discriminate regional from local anomalies. The factor analysis applied to the geochemical data successfully depicted the geochemical background, with the definition of large domains, similar to the ones produced by the unsupervised classification technique based on geochemical, spectrorradiometric, and orbital remote sensing data. A better characterization of the local anomalies was obtained by overlapping the $\mathrm{Cu}$ residuals on top of the Factor 1 scores, or by the interpretation of some classes from the unsupervised classification. This technique, together with those based on geographical information systems, allowed a significant reduction of the area of greater mineral potential for mineral exploration.

It should be pointed out, however, that these methods introduce some uncertainty as a function of the need for interpolating geochemical data in the process to produce raster image data. The minimum distance between mineral occurrences and local anomalies was 0.6 - 1.6 kilometers for dot maps (specially regression residuals for $\mathrm{Cu}$ ) and $1.3-2.0$ kilometers for raster integrated maps (unsupervised classification or GIS techniques). This distance is quite close to the inter-sample distance and seems adequate for regional scale studies. Remote sensing data did not have the same problem, but were almost certainly affected by vegetation cover, in particular by grasslands, which are an essential element of the prairie in the Uruguayan territory.

Nine local anomalies were defined by statistical processing of the geochemical data. Two of them were considered as lithological anomalies after integration with geological and remote sensing data. The other seven local anomalies could be related to mineralization phenomena. Three of them include known mineral occurrences of $\mathrm{Pb}$ and an old Au mine. The other known mineral occurrence $(\mathrm{Cu}-\mathrm{Fe})$ was masked by a regional anomaly of the Fe-group elements near Zapicán village. The remaining four local anomalies can be considered as potential targets for follow-up exploration. Two of them are related to granites intruded into the Pavas formation, showing multivariate associations and good spatial distribution of samples. The third one is related to Barriga Negra Group, and the last showed geologic and geochemical similarities with the local anomaly of the old Au mine.

Geochemical data used in this study had some precision problems and results could be damaged. Future studies with new analytical methods (ICP-MS, INAA....) may be an important contribution to improve environmental and mineral knowledge of the area.

\section{Acknowledgements}

To the Åbo Akademi University (Finland), the Geological Survey of Finland, the Laboratory for GeoReferenced Information Processing (LAPIG) of the Geosciences Institute, State University of Campinas (UNICAMP) and the Geoprocessing Laboratory of EMBRAPA, Temperate Region Center, for allowing the use of their facilities. Financial support for acquiring Landsat-TM digital images was received from FAPESP. J. M. Filippini-Alba was supported by a Ph.D. grant from Conselho Nacional de Desenvolvimento Científico e Tecnológico (CNPq). To Dr. Asit Choudhuri, from the Geosciences Institute, State University of Campinas, for reviewing the final manuscript and to two anonimous referees of RBG for the critical review of the original. 


\section{References}

Ahlsved C., Lampio E., Tarvainen T. 1991. ALKEMIA-a VAX minicomputer database program package for geochemical exploration. Journal of Geochemistry Exploration, 41:23-28.

Bonham-Carter G. 1994. Geographic Information Systems for Geoscientists. Ontario, Pergamon. 398p.

Bonham-Carter G., Agterberg F., Wright D. 1988. Integration of geological datasets for gold exploration in Nova Scotia. Photogrammetric Engineering and Remote Sensing, 54:1585-1592.

Crósta A. P. 1991. High resolution geochemistry and satellite data integration: application to mineral exploration in a tropical environment. In: Eighth Thematic Conference on Geological Remote Sensing. Denver, Proceedingss, 2:1335-1348.

Crósta A. P. 1993. Processamento Digital de Imagens de Sensoriamento Remoto. Campinas, UNICAMP, 170p.

Crósta A. P. \& Moore J. McM 1989. Enhancement of Landsat Thematic Mapper imagery for residual soil mapping in SW Minas Gerais state, Brazil: a prospecting case history in greenstone belt terrain. In: Seventh Thematic Conference of Remote Sensing for Exploration Geology, Calgary. Proceeding.s, 2:1173-1187.

Crósta A. P. \& Rabelo A. 1993. Assessing Landsat/TM for hydrothermal alteration mapping in Central-Western Brazil. In: Ninth Thematic Conference on Geological Remote Sensing. Pasadena, Proceedings, 1:1053-1061.

Darnley A., Björklund A., Bölviken B., Gustavsson N., Koval P., Plant J., Steemfelt A., Tauchid M., Xie Xuejing 1995. A global geochemical database for environmental and resource management. Final Report of IGCP Project 259. Paris, UNESCO, 122p. (Earth Sciences 19).

ERM 1995. ER-Mapper 5.0: Applications. West Perth, Earth Resource Mapping, 372p.

Fay A. 1982a. Esbozo Geológico del Fotoplano Pirarajá a la escala 1/50.000. Montevidéu, DINAMIGE, 1 map.

Fay A. 1982b. Esbozo Geológico del Fotoplano Zapicán a la escala 1/50,000. Montevidéu, DINAMIGE, 1 map.

Fay A. 1982c. Esbozo Geológico del Fotoplano José P. Varela a la escala 1/50.000. Montevidéu, DINAMIGE, 1 map.

Fesefeldt K. 1988. Asesoramiento geológico y yacimentológico a la DINAMIGE. Hannover, BGR, 186p. (Project Repor 842024.2)

Filippini-Alba J. 1990. Prospección geonuímica en los alrededores de la Mina abandonada Presidente Terra. Montevidéu, DINAMIGE, 30p.

Filippini-Alba J. 1998. Análise e integração de dados geoquímicos e de sensoriamento remoto em um setor do cristalino uruguato. Inst. Geociências, Universidade de São Paulo, São Paulo, PhD thesis, 172p.

Fragoso-Cesar A., Machado R., Gómez-Rifas C. 1987. Observações sobre o Cinturão Dom Feliciano no Escudo Uruguaio e correlações com o Escudo do Rio Grande do Sul. In: SBG, III Simpósio Sul-Brasileiro de Geologia, Curitiba, 1987. Atas, 2:791-809.

Gómez-Rifas C. 1995. A zona de cisalhamento sinistral Sierra Ballena no Uruguai. Inst. Geociências, Universidade de São Paulo, São Paulo, PhD thesis, 244p.

Govet G. 1983. Rock Geochemistry in Mineral Exploration. Amsterdam, Elsevier, 461p. (Handbook of Exploration Geochemistry, 3).
Govett G. \& Atherden G. 1988. Application of rock geochemistry to productive plutons and volcanic sequences. Journal of Geochemical Exploration, 30:223-242.

GRASS 1991. Geographic Resources Analysis Support System (Version 4.0). Champaign, U.S. Army Corps of Engineers, Construction Engineering Research Laboratory.

Harris J. 1989. Data integration for gold exploration in Eastern Nova Scotia using a GIS. In: Seventh Thematic Conference on Remote Sensing for Exploration Geology. Calgary, Proceedings, 1:233-249.

IGU-BRGM 1982. Inventario Minero del Uruguay - Primera Fase. Orleáns, BRGM, 83p. (Final Report).

Illanes L. 1982. Esbozo Geológico del Fotoplano Gutiérrez a la escala 1/50.000. Montevidéu, DINAMIGE, 1 map.

Kuosmanen V., Arkimaa H., Gaál G., Huhtala T., Koistinen E., Lindovist E., Murtoniemi S. Nikander J., Ruskeeniemi K., Salonen V., Talvitie J., Tenhola M., Tiainen M. Ward P. 1988. Exploration target selection by integration of geodata using statistical and image processing techniques: an example from central Finland._Part I (Text). Espoo, Geological Survey of Finland. 156 p. (Investigation Report 80)

Loughlin W. 1991. Principal Component Analysis for Alteration Mapping. Phogrammetric Engineering and Remote Sensing, 57:1163-1170.

Preciozzi F. 1987a. Carta Geológica del Uruguay Escala 1:100.000. Memoria Explicativa del Fotoplano José P. Varela (E-21). Montevidéu, DINAMIGE-FA-FHC, 11 p., I map.

Preciozzi F. 1987b. Carta Geológica del Uruguay Escala 1:100.000. Memoria Explicativa del Fotoplano Zapicán (F-22). Montevidéu, DINAMIGE-FA-FHC, 12 p., 1 map.

Preciozzi F.; Fay A. 1988. Carta Geológica del Urugaay Escala 1:100.000. Memoria Explicativa del Fotoplano Pirarajá $(F-23)$. Montevidéu, DINAMIGE-FA-FHC. 15 p., I map.

Preciozzi F., Spoturno J., Heinzen W., Rossi P. 1985. Carta Geológica del Uruguay. Escala 1:500.000. Montevidéu, DINAMIGE, 1 map.

Preciozzi F., Spoturno J., Heinzen W., Rossi P. 1988. Memoria Explicativa de la Carta Geológica del Uruguay Escala 1:500.000. Montevidéu, DINAMIGE, 92p.

Silva A. B. 1993. Mineral exploration in Northeastern Brazil: a data fusion aproach and a GIS strategy. In: Ninth Thematic Conference on Remote Sensing for Exploration Geology. Pasadena, Proceedings, 2:55-63.

SPSS 1993. SPSS for Windows: Professional Statistics. Realese 6.0. Chicago-USA, SPSS Inc.

SYSTAT 1992. SYSTAT: Statistics (Version 5.2). Evanston, SYSTAT, Inc., 724p.

SURFER 1994 Surfer for Windows. Golden-Co, Golden Software.

Tiainen M. \& Viita H. 1994. Determination of ore potential areas in the Häme Belt, Southwestern Finland, by integration of geological, geophysical and till geochemical data. Espoo, Geological Survey of Finland. 49p (Investigation Report 125).
Manuscrito A-1144

Recebido em 31 de janeiro de 2000 Revisão dos autores em 15 de fevereiro de 2001 Revisão aceita $\mathrm{em} 22$ de fevereiro de 2001 